\title{
HUBUNGAN PENGETAHUAN DAN MINAT IBU MULTIPARA MENGGUNAKAN KB MOW \\ (Di Desa Mojokendil, Kec. Ngronggot,Kab. Nganjuk)
}

Hj. Rimurdayati, SPd.S.ST.M.M. Kes ${ }^{1}$, Shinta Trisnawati ${ }^{2}$

Akademi Kebidanan Dharma Husada Kediri

\begin{abstract}
ABTRAK
Kontrasepsi MOW (Metode Operasi Wanita), merupakan salah satu metode kontrasepsi yang sangat menguntungkan karena efektiitasnya yang sangat tinggi untuk mengakhiri kesuburan. Namun pada kenyataanya masih sedikit jumlah pengguna kontrasepsi ini. Hal ini disebabkan pengetahuan yang kurang akan kontrasepsi MOW dan minat yang masih rendah.

Rancangan penelitian yang digunakan adalah korelasional, dengan pendekatan cross sectional. Populasinya adalah semua Ibu multipara di Desa Mojokendil, Kecamatan Ngronggot, Kabupaten Nganjuk sejumlah 103 ibu.Teknik sampling menggunakan purposive sampling yaitu sejumlah $51 \mathrm{ibu}$.Variabel independennya adalah pengetahuan dan variabel dependennya adalah minat ibu tentang KB MOW.Data diperoleh dari kuesioner, setelah itu pengolahan data dengan editing, coding, scoring, tabulating, kemudian di analisa menggunakan Spearman Rank.

Hasil penelitian ini menunjukan bahwa banyak responden yang masih memiliki pengetahuan yang kurang yaitu 38 orang ( $74.50 \%$ ). Dan minat yang rendah yaitu 36 responden (70.59\%).Dari penelitian yang telah dilakukan didapatkan kesimpulan bahwa pengetahuan yang rendah juga mempengaruhi minat seseorang yang rendah pula. Hal tersebut dipengaruhi oleh beberapa faktor diantara lain adalah usia, informasi, pendidikan dan pekerjaan. Karena pengetahuan ibu multipara yang rendah maka rendah pula minat ibu multipara menggunakan kontrasepsi MOW.

Dari hasil penelitian tersebut maka kita sebagai petugas kesehatan harus meningkatkan pengetahuan ibu multipara tentang kontrasepsi mantap wanita. Dengan cara memberi penyuluhan mengenai kontrasepsi mantap wanita, membagikan leaflet tentang KB MOW. Diharapkan ibu bisa menyerap pengetahuan dan dapat berminat dalam menggunakan kontrasepsi mantap wanita.
\end{abstract}

Kata kunci : KB MOW, Multipara, Pengetahuan, Minat. 


\section{PENDAHULUAN}

Salah satu masalah terpenting yang dihadapi oleh Negara berkembang seperti di Indonesia yaitu ledakan penduduk.Ledakan penduduk mengakibatkan laju pertumbuhan penduduk (LPP) yang sangat pesat hal ini dikarenakan kurangnya pengetahuan dari masyarakat setempat. Karenanya diperlukan kerja sama antara pemerintah, masyarakat dan lembagalembaga terkait lainya untuk menanggulangi ledakan penduduk di Indonesia. Untuk mengatasi masalah tersebut, pemerintah mengupayakan menekan laju pertumbuhan penduduk melalui program Keluarga Berencana (KB).

Keluarga Berencana (KB) merupakan suatu program pemerintah yang dirancang untuk menyeimbangkan antara kebutuhan dan jumlah penduduk.Program keluarga berencana oleh pemerintah adalah agar keluarga sebagai unit terkecil kehidupan bangsa diharapkan menerima Norma Keluarga Kecil Bahagia dan Sejahtera (NKKBS) yang berorientasi pada pertumbuhan yang seimbang. (Irianto, 2014: 6)

Di Indonesia Keluarga Berencana modern mulai dikenal pada tahun 1953.Pada waktu itu, sekelompok ahli kesehatan, kebidanan, dan tokoh masyarakat telah mulai membantu masyarakat tetapi dengan sedikit mungkin publisitas, dengan menggunakan obat yang ada untuk menjalankan keluarga berencana.

Walaupun pemakaian metode keluarga berencana jelas berperan dalam menurunkan angka kematian ibu dan meningkatkan kelangsungan hidup anak, sebagian wanita mungkin enggan

Menurut Dinas Kesehatan tahun 2015 total peserta KB aktif di Jawa Timur sebanyak 6.150 .153 orang atau $76,95 \%$ terhadap jumlah Pasangan Usia Subur (PUS) 7.992.674 peserta. Dari 6.150.153 peserta $\mathrm{KB}$ aktif, pengguna $\mathrm{KB}$ suntik sebanyak 48,2\%, Pil $21,01 \%$, IUD atau memakai suatu metode kontrasepsi karena takut akan komplikasinya. Walaupun pada kenyataanya bahwa sebagian besar metode memiliki resiko minimal, ada insiden-insiden tertentu berupa penyakit atau kematian yang dapat menyebabkan meluasnya rumor dan salah informasi mengenai metode kontrasepsi dalam masyarakat. (WHO, 2007: 15)

Di dunia ini, kira-kira 85 dari 100 wanita yang aktif secara seksual tidak menggunakan metode kontrasepsi apapun, sehingga terjadi kehamilan dalam waktu 1 tahun 1 dan lebih dari seperempat wanita yang hamil melakukan pengguguran. Hasil sementara SDKI tahun 2007 menyebutkan, saat ini sebanyak 39\% wanita indonesia usia reproduktif yang tidak menggunakan kotrasepsi, dengan sebaran $40 \%$ di pedesaan dan $37 \%$ di perkotaan (BKKBN, 2007). Hasil sementara survey demografi dan Kesehatan Indonesia (SDKI) tahun 2007 menyebutkan pola pemakaian suntik sebesar 31.6\% (BKKBN).

Profil kesehatan Indonesia tahun 2015 mencatat bahwa estimasi jumlah Wanita Usia Subur (WUS) tahun 2015 sejumlah 67.133 .347 orang, atau sekitar $27,4 \%$ total estimasi jumlah penduduk di Indonesia tahun 2015. Data Riskesdas $2010 \quad$ menyebutkan perkawinan pertama terbesar terjadi pada wanita berusia 15-19 tahun, yaitu $41,9 \%$. Besarnya jumlah wanita usia subur dan usia muda yang telah melakukan perkawinan pertama di Indonesia membutuhkan perhatian khusus untuk dapat menjaga kesehatan reproduksi sehingga mendukung peningkatan kesehatan ibu dan penurunan Angka Kematian Ibu. (BKKBN)

spiral 14\%, Implan $8.5 \%$, MOW 5\%, kondom $\quad 1.5 \%, \quad$ sementara penggunaMOP $\quad 0.4 \%$. (Dinkes Jawa Timur, 2015)

Dari data diatas diketahui prosentase semua 
jenis kontrasepsi yang digunakan oleh pasangan usia subur. Dan diketahui bahwa berdasarkan data diatas, kontrasepsi yang paling sedikit peminatnya adalah kontrasepsi MOW, Setelah diulas ulang ternyata kurang nya peminat dari KB MOW adalah dikarenakan kurangnya pengetahuan ibu akan kontrasepsi KB MOW sehingga ibu tidak berminat dalam menggunakan KB MOW.

Menurut World Population Data Sheet 2013, Indonesia merupakan Negara ke-5 di dunia dengan estimasi jumlah penduduk terbanyak yaitu 249 juta. Diantara Negara ASEAN, Indonesia dengan luas wilayah terbesar tetap menjadi Negara dengan penduduk terbanyak, jauh diatas 9 negara anggota lain. Dengan angka fertilitas atau Total fertility Rate (TfR) 2.6 Indonesia masih berada di atas rata-rata TfR negara ASEAN, yaitu 2.4.

Menurut Dinas Kesehatan Kabupaten Nganjuk tahun 2015, tercatat total PUS 7.992 orang dari PPM (Prakiraan Permintaan Masyarakat). Total peserta KB aktif sebanyak 6.150 orang. Multipara tercatat 2.650 orang. Dengan prevalensi pengguna KB suntik $48.02 \%$, peserta KB pil $21.01 \%$, peserta KB IUD $14 \%$, peserta $\mathrm{KB}$ Implant $8.5 \%$, peserta $\mathrm{KB}$ MOW 5\%,peserta KB kondom $1.5 \%$, sementara pengguna KB MOP $0.4 \%$. Berdasarkan data dari ibu multipara tercatat pengguna $\mathrm{KB}$ suntik $50 \%$, peserta $\mathrm{KB}$ pil $18 \%$, peserta KB implant $8,5 \%$, peserta KB IUD 5\%, dan peserta KB MOW 4\%. (Dinkes Nganjuk, 2015)
Menurut pertemuan LMD Desa Mojokendil Kec. Ngronggot Kab.Nganjuk, tercatat 15 dari $20 \mathrm{ibu}$ tidak mengetahui dengan jelas tentang KB MOW. Rata-rata ibu sudah berusia lebih dari 35 tahun dan sudah mempunyai anak lebih dari dua. Mereka belum mengetahui dengan jelas apa dan bagaimana KB MOW.

\section{METODE}

Pada penelitian ini desain desain penelitian yang digunakan adalah studi korelasi dengan pendekatan Cross Sectional.Studi korelasi merupakan penelitian hubungan antara dua variabel pada suatu situasi atau kelompok subyek. Populasi dalam penelitian ini adalah semua ibu multipara di Desa. Mojokendil Kec. Ngronggot Kab. Nganjuk, berjumlah 103 Ibu.

Dalam penelitian sampelnya adalah sebagian ibu multipara di Desa. Mojokendil Kec. Ngronggot Kab. Nganjuk, yang memenuhi kriteria inklusi.Disini peneliti dalam pengambilan sampel menggunakan rumus besar sampel yaitu sejumlah 51 ibu.

Adapun kriteria inklusinya adalah sebagai berikut:

a. Ibu yang dapat membaca dan menulis.

b. Ibu yang memiliki anak $\geq 2$

c. Ibu yang berumur $\geq 35$ tahun.

kriteria eksklusi yaitu akseptor yang tidak bersedia dijadikan responden.

Pengambilan sampel dalam penlitian ini menggunakan teknik Purposive Sampling

\section{HASIL}

a. Pengetahuan Ibu Multipara Tentang KB MOW.

\begin{tabular}{clcc} 
No & Pengetahuan & Frekuensi & Prosentase (\%) \\
\hline 1 & Baik & 5 & 9,80 \\
\hline 2 & Cukup & 8 & 15,70 \\
\hline 3 & Kurang & 38 & 74,50 \\
\hline \multirow{2}{*}{ Total } & 51 & 100
\end{tabular}


Berdasarkan tabel I menunjukan 51 responden yang diteliti dan telah dilakukan pengolahan data didapatkan pengetahuan ibu multipara tentang KB MOW dengan kriteria tertinggi yaitu kurang 38 responden $(74,50 \%)$ dan dengan kriteria baik 5 responden $(9,80 \%)$.

\section{b. Minat Ibu Multipara menggunakan KB MOW}

\begin{tabular}{cccc} 
No & Kriteria & Jumlah & Prosentase (\%) \\
\hline 1 & Tinggi & 5 & 9,80 \\
\hline 2 & Sedang & 10 & 19,60 \\
\hline 3 & Kurang & 36 & 70,59 \\
\hline & Total & 51 & 100
\end{tabular}

Berdasarkan tabel II menunjukan 51 responden yang diteliti dan telah dilakukan pengolahan data didapatkan minat ibu multipara menggunakan KB MOW dengan kriteria tertinggi yaitu kurang 36 responden $(70,59 \%)$ dan dengan kriteria baik 5 responden $(9,80 \%)$.

\section{c. Hubungan Pengetahuan Dan Minat Ibu Multipara Menggunakan KB} MOW

\begin{tabular}{lcccccccc}
\multirow{2}{*}{$\begin{array}{l}\text { Minat } \\
\text { Pengetahtran }\end{array}$} & \multicolumn{2}{c}{ Tinggi } & \multicolumn{2}{c}{ Sedang } & \multicolumn{2}{c}{ Rendah } & \multicolumn{2}{c}{ Jumlah } \\
\cline { 2 - 10 } & $\mathbf{N}$ & $\mathbf{\%}$ & $\mathbf{N}$ & $\mathbf{\%}$ & $\mathbf{N}$ & $\mathbf{\%}$ & $\mathrm{N}$ & $\mathbf{\%}$ \\
\hline Baik & 3 & 5,88 & 3 & 5,88 & 0 & 0 & 6 & 11,76 \\
\hline Cukup & 2 & 3,92 & 3 & 5,88 & 3 & 5,88 & 8 & 15,69 \\
\hline Kurang & 4 & 7,84 & 10 & 19,6 & 23 & 45,1 & 37 & 72,55 \\
\hline \multicolumn{1}{c}{ Total } & 9 & 17,64 & 16 & 31,37 & 26 & 50,98 & 51 & 100
\end{tabular}

Berdasarkan hasil pengamatan dari table silang III diatas

1) Menunjukan bahwa dari 51 responden didapatkan 3 responden $(5,88 \%)$ mempunyai pengetahuan baik dengan minat tinggi, sebanyak 2 responden $(3,92 \%)$ mempunyai pengetahuan cukup dengan minat tinggi, sebanyak 4 responden $(7,84 \%)$ mempunyai pengetahuan kurang dengan minat tinggi.

2) Menunjukan bahwa dari 51 responden didapatkan 3 responden $(5,88 \%)$ mempunyai pengetahuan baik dengan minat sedang, sebanyak 3 responden $(5,88 \%)$ mempunyai pengetahuan cukup dengan minat sedang, sebanyak 10 responden $(19,6 \%)$ mempunyai pengetahuan kurang dengan minat sedang.

3) Menunjukan bahwa dari 51 responden didapatkan 0 responden $(0 \%)$ mempunyai pengetahuan baik dengan minat rendah, sebanyak 3 responden $(5,88 \%)$ mempunyai pengetahuan sedang dengan minat rendah, sebanyak 23 responden $(45,1 \%)$ mempunyai pengetahuan kurang dengan minat rendah.

\section{DISKUSI}

\section{Pengetahuan Ibu Multipara tentang KB MOW}

Berdasarkan penelitian yang telah dilakukan didapatkan bahwa pengetahuan responden tentang $\mathrm{KB}$ MOW masih kurang yaitu dengan prosentase $74,50 \%$, berpengetahuan cukup dengan prosentase $15,70 \%$, dan baik sejumlah $9,80 \%$. Disini dapat disimpulkan bahwa sebagian besar pengetahuan ibu multipara tentang $\mathrm{KB}$ MOW masih rendah.

Pengetahuan adalah hasil penginderaan manusia, atau hasil tahu seseorang terhadap objek melalui indra yang dimilikinya (mata, hidung, telinga dan sebagainya). Dengan sendirinya, pada waktu penginderaan sampai menghasilkan pengetahuan tersebut sangat dipengaruhi oleh intensitas 
perhatian dan persepsi terhadap objek. (Notoatmodjo, 2010: 50)

Pengetahuan merupakan keahlian dan ketrampilan ketrampilan yang diperoleh oleh seseorang melalui pengalaman atau pendidikan. Pengetahuan ini dipengaruhi oleh berbagai faktor antara lain pendidikan dan pekerjaan. Dari tahun ke tahun dan bertambahnya pengalaman maka pengetahuannya juga akan bertambah. Semakin banyak pengetahuan makan akan semakin luas wawasan seseorang. Karena dengan pengetahuan maka orang tersebut akan mengerti dengan sesuatu, dengan begitu orang tersebut mengerti maksud dan tujuan dari sesuatu. Maka akan akan mendorong orang tersebut untuk menjadi lebih tau.

\section{Minat Ibu Multipara Menggunakan KB MOW Berdasarkan penelitian} yang telah dilakukan didapatkan bahwa minat responden menggunakan $\mathrm{KB}$ MOW masih rendah, yaitu dengan prosentase $70.59 \%$, minat sedang dengan prosentase $19.60 \%$, dan tinggi sejumlah $9.80 \%$. Disini dapat disimpulkan bahwa minat ibu multipara menggunakan KB MOW masih relative kurang.

Minat adalah suatu yang pribadi dan berhubungan dengan sikap. Minat merupakan sumber motivasi yang mendorong orang untuk melakukan apa yang mereka inginkan. (Wordpress, 2010)

Dari hasil penelitian minat responden adalah masuk dalam kategori sedang dan rendah. Dimana minat tersebut dipengaruhi oleh faktor usia dan informasi yang didapatkan. Karena sebagian besar ibu multipara memiliki pengetahuan yang rendah segingga faktanya ibu multipara mempunyai minat yang rendah pula terhadap kontrasepsi mantap wanita. Minat sangat berhubungan erat dengan pengetahuan. Tingkat pengetahuan yang rendah akan menghambat pemahaman dan kemampuan responden mencerna informasi yang didapat sehingga cenderung memiliki minat yang rendah, sedangkan tingkat sedangkat tingkat pendidikan yang tinggi akan cenderung memiliki minat yang tinggi, karena mereka dapat mencerna informasi yang didapat. Sebagian besar responden memiliki pendidikan yang menengah ke bawah, sehingga mereka kurang memiliki kesadaran dalm menumbuhkan mintanya untuk menggunakan kontrasepsi mantap wanita.

\section{Hubungan Pengetahuan dan Minat Ibu Multipara Menggunakan KB MOW}

Dari hasil penelitian yang dilakukan terhadap 51 responden di Desa Mojokendil Kecamatan Ngronggot Kabupaten Nganjuk, diperoleh hasil pengetahuan yang kurang mempengaruhi minat yang rendah pula terhadap seseorang.

Menurut Supriatna (2009:33) minat erat hubungannya dengan pengetahuan, karena pengetahuan yang tinggi akan menimbulkan ketertarikan, perhatian dan juga termotivasi terhadap suatu obyek tertentu. Maka dari itu pengetahuan sangat berhubungan dengan minat.

Program KB nasional dilakukan salah satu diantaranya yakni mengakhiri kehamilan dengan metode yang paling efektf yaitu Metode Operasi Wnita (MOW), khususnya untuk Pasangan Usia Subur (PUS) wanita usia minimal 35 tahun dan telah meliliki dua anak atau lebih. Oleh karena itu pengikutsertaan pasangan usia subur wanita dalam kependudukan dan KB merupakan usaha yang sagat tepat sebab MOW sangat efektif dan aman bagi hampir semua pasangan usia subur wanita yang tidak ingin mempunyai anak lagi terutama bagi pasangan yang masih relative muda karena tidak mengurangi gairah seks. 


\section{SIMPULAN}

1. Sebanyak 38 responden ( $74.50 \%$ ) yaitu sebagian besar ibu multipara memiliki pengetahuan yang rendah tentang kontrasepsi MOW.

2. Sebayak 38 responden ( $70.59 \%$ ) yaitu sebagian besar ibu multipara memiliki

\section{DAFTAR PUSTAKA}

Arikunto, Suharsimi. 2006. Prosedur Penelitian Suatu Pendekatan Praktik. Jakarta: PT.Rineka Cipta.

Everett, Suzanne. 2008. Buku Saku Kontrasepsi \& Kesehtan Seksual Reproduksi. Jakarta: EGC.

Hartanto, Hanafi. 2010. Keluarga Berencana dan Kontrasepsi. Jakarta: Pustaka Sinar Harapan

Iqbal, Hasan. 2010. Analisis Data Penelitian Dengan Statistik. Jakarta: Bumi Aksara.

Mochtar, Rustam. 2012. Sinopsis Obstetri Jilid 2. Jakarta: EGC

Nursalam, 2010.Keperawatan: Pedoman Skripsi, Tesis dan Instrumen Penelitian. Jakarta: Salemba Medika.

Pusat Bahasa Departemen Pendidikan Nasional. 2012. Kamus Besar Bahasa Indonesiaedisi 3. Jakarta: Balai Pustaka. 2008. Kamus Besar Bahasa Indonesiaedisi 3. Jakarta: Ba;ai Pustaka.

Setiadi. 2007. Konsep \& Penulisan Riset Keperawatan. Yogyakarta: Graha Ilmu.

Sugiono. 2011. Metode Penelitian Administrasi Dilengkapi dengan Metode $R \& D$. Bandung : CV. Alfabeta. minat yang kurang dalam menggunakan kontrasepsi MOW.

3. Ada hubungan antara pengetahuan dan minat ibu multipara menggunakan $\mathrm{KB}$ MOW dengan rumus penghitungan didapatkan hasil yaitu $r_{S}$ hitung $>$ $r_{s}$ tabel yaitu $0.956>0.364$.

Sulistyawati, ari. 2009. Buku Ajar Asuhan Kebidanan. Yogyakarta: ANDI.

Wawan.A \& Dewi M, 2011. Teori \& Pengukuran Sikap \& Perilaku Manusia. Yogyakarta: Nuha Medika.

WHO. 2007. Ragam Metode Kontrasepsi. Jakarta: EGC.

BKKBN. 2016. Penundaan Kehamilan. [Internet] 25 April 2016. Available from: bkkbn.go.id 2016. Gambaran Akseptor KB Metode Operatif. Available from: kti-skripsi.com. [Internet] 26 April 2016.

Sastra_geologi. 2016. Kontrasepsi MANTAP. Available from: duniasastrageologi.blogspot.com. [Internet] 26 April 2016.

Suparyanto, 2010. Referensi Kesehatan. Available from http ://creasoft.wordpress.com. [Internet] 26 April 2016.

Suparyanto, 2010. Konsep Dasar Minat. Available from http ://drsuparyanto.wordoress.com. [Internet] 26 April 2016. 